\title{
Abuses of Shareholders Derivative Suits: How Far Is California's New "Security For Expenses" Act Sound Regulation?
}

\author{
Henry W. Ballantine*
}

The California Legislature has taken an important step in a very controversial problem by adding to the Corporations Code, Section 834. ${ }^{2}$ This 1949 act is designed to protect corporations, their directors, officers and employees against so-called "strike suits" and the litigation expenses which may be unjustifiably foisted upon them. Stringent statutes with this aim in view have recently been adopted in New York, and, following that questionable example, in New Jersey, Pennsylvania and Wisconsin. ${ }^{2}$

The New York act gave impetus to the California legislation and in part served as a source, but not as a model, for it. The proposal as originally made in Assembly Bill 428 copied in substance the New York General Corporation Law provisions. As a result of opposition that developed, a conference was arranged by the sponsors of the bill, and the worst features of the New York act were eliminated. Certain questionable provisions of the New York law have, however, been included, and some have even been exceeded. The New York act is said to be an outgrowth of the statutory scheme for reimbursement by the corporation of successful officials and employees sued in derivative actions on behalf of corporations. ${ }^{3}$ The California act goes even beyond that and imposes liability on the plaintiff for expenses of successful stranger defendants under certain conditions.

\footnotetext{
* Professor of Law, University of California.

1 Cal. Stats. 1949, Chapter 499, approved by the Governor June 3, effective October 1, 1949.

2New York Laws 1944, c. 869, adding \$ 61b to the General Corporation Law; New Jersey Revised Statutes, Cum. Supp. 14:3-15, N.J.S. A. 14:3-15 added by New Jersey Laws, 1945, c. 131; Pennsylvania Statutes Annotated (Purdon, Supp. 1945) title $12 \S 1322$, added by Pennsylvania Laws, 1945, Act No. 114 \& 2. The Maryland statute excludes attorneys' fees from the expenses for which security must be given. Maryland Laws, 1945, c. 989. The Wisconsin statute (Wisc. Stat. (1945) § 180.13(3)) provides that no derivative suit shall be maintained against directors or officers of a Wisconsin corporation by holders of less than $5 \%$ of the outstanding stock of "any" class, "unless the action is one based on conduct which results, and is wilfully intended to result, in a direct or indirect personal benefit or advantage to one or more directors or officers, or conduct which results in a personal benefit or advantage to one or more stockholders over the other stockholders." This peculiar statute is criticized ably in a note in (1948) Wisc. L. REv. 580, 586, 588.

${ }^{3}$ Schielcrawt v. Moffett (1945) 294 N. Y. 180, 61 N. E. (2d) 435; CaLIF. Corp. Code $\$ 830 ;$ N. Y. Gen. Corp. Law \$§ 64-68; 1948 ANNuAd Survey of AmERICAN LAw, New York University School of Law 504, Corporations, by M. A. de Capriles (1949).
} 
The problem of regulation of shareholders' suits to prevent abuses is no easy one. It has long been evident that derivative suits, though useful and necessary to redress the frauds of management, are susceptible of abuse when brought without reasonable or probable cause and from dishonest motives of extortion or private settlement." Alternative remedies have been proposed as a way of obviating abuses but none of them has appeared adequate or satisfactory.

\section{Stringency of Legislation}

The very drastic New York act (Section 61b), the first of its kind, was vigorously attacked as unconstitutional. Its constitutionality was upheld, after conflict in the lower courts, by the New York Court of Appeals. ${ }^{6}$ The New Jersey act, which follows in general the New York act, although it is even more harsh, has recently been held constitutional by the United States Supreme Court in Cohen v. Beneficial Industrial Loan Corporation, ${ }^{7}$ although the wisdom and policy of the law were expressly not passed upon. In the opinion of Justice Jackson it was declared:

The very nature of the stockholder's derivative action makes it one in the regulation of which the legislature of a state has wide powers. ... a stockholder who brings suit on a cause of action derived from the corporation assumes a position, not technically as a trustee perhaps, but one of a fiduciary character. He sues, not for himself alone, but as representative of a class comprising all who are similarly situated. The interests of all in the redress of the wrongs are taken into his hands, dependent upon his diligence, wisdom and integrity. And while the stockholders have chosen the corporate director or manager, they have no such election as to a plaintiff who steps forward to represent them. He is a self-chosen representative and a volunteer champion. The Federal Constitution does not oblige the State to place its litigating and adjudicating processes at the disposal of such a representative, at least without imposing standards of

4 Note (1949) 23 Sr. JoHn's L. Rev. 296; Note, Extortionate Corporate Liligation: The Strike Stit (1934) 34 Cot. L. Rev. 1308; Ballantine, Corporatrons 356 (1946); Wood, Survey and Report Regarding Stockholders Derivalive Suits 82, Cramber or COMMIERCE OF STATE OF NEw YORK (1944). See Hornstein's criticism of this report in (1944) 32 CALIF. L. REv. 123, 126-141.

5 Berlack, Stockholders' Suits: A Possible Substitute (1937) 35 Micr. L. Rev. 597, 607, 608 (suit by government agency); Laswell, $A$ Nost-Bureancratic Allernative to Minority Stockholders' Suits (1943) 43 Cor. L. Rev. 1036 (a stockholders' reporting service on a non-profit fee basis); a reply by A. H. Dean (1943) 43 CoL. L. REv. 1040; a reply by Podell (1943) 43 Cor. L. REv. 1045 (government agency); Note (1946) 13 U. OF CHI. L. REv. 321, 329.

${ }^{B}$ Lapchak v. Baker (1948) 298 N.Y. 89, 80 N. E. (2d) 751, noted (1949) 24 N.Y. U. L. Q. REv. 395. See Beneficial Industrial Loan Corp. v. Smith (C. C. A. 3d 1948) 170 F. (2d) 44 ; Note (1949) 23 St. JoHN's L. Rev. 296.

7 (1949) 337 U.S. 541 , affirming Beneficial Industrial Loan Corporation v. Smith (C. C. A. 3d 1948) $170 \mathrm{~F}$. (2d) 44. 
responsibility, liability and accountability which it considers will protect the interests he elects himself to represent. It is not without significance that this Court has found it necessary long ago in the Equity Rules and now in the Federal Rules of Civil Procedure to impose procedural regulations of [sic] the class action not applicable to any other. We conclude that the state has plenary power over this type of litigation.

... The wisdom and the policy of this and similar statutes are involved in controversies amply debated in legal literature but not for us to judge, and, hence not for us to remark upon. The Federal Constitution does not invalidate state legislation because it fails to embody the highest wisdom or provide the best conceivable remedies. Nor can legislation be set aside by courts because of the fact, if it be such, that it has been sponsored and promoted by those who advantage from it. In dealing with such difficult and controversial subjects, only experience will verify or disclose weaknesses and defects of any policy and teach lessons which may be applied by amendment. Within the area of constitutionality, the states should not be restrained from devising experiments, even those we might think dubious, in the effort to preserve the maximum good which equity sought in creating the derivative stockholder's action and at the same time to eliminate as much as possible its defects and evils.

Before the New York statute, effective April 9, 1944, a shareholder in New York, owning a single share of stock out of $6,000,000$ or more, might have instituted and maintained a shareholder's derivative suit in behalf of his corporation, incurring if defeated only liability for his own court costs and counsel fees as in any ordinary suit. He would not have been liable for the corporation's and other defendants' counsel and accountants' fees and could not have been compelled to give security for the expenses of the parties defendant. ${ }^{8}$ The same situation exists in California and will exist until October $1,1949$.

The New York Security-for-Expenses Act ${ }^{2}$ provides that the holder of less than five per cent of the outstanding shares of "any" class of such corporation's stock or voting trust certificates, ${ }^{10}$ unless his holdings have a market value in excess of $\$ 50,000$, may be required on motion of the corporation in whose right the action is brought, at any stage of the proceedings before final judgment (1) to give security for the reasonable expenses including attorneys' fees, (2) which may be incurred by it in connection with such action, (3) or by the other parties defendant for which it may become liable

8 Schielcrawt v. Moffett (1945) 294 N. Y. 180, 61 N. E. (2d) $435,437$.

9N. Y. GEN. CORP. LAW \& $61 \mathrm{~b}$.

10 Does this mean "of all classes outstanding," or five per cent of "any one class"? See Noel Associates Inc. v. Merrill (Sup. Ct. 1944) 184 Misc. 646, 53 N.Y.S. (2d) 143. Compare New Jersey act, infra. 
under section 64 of the General Corporation Law, (4) to which security "the corporation shall have recourse in such amount as the court having jurisdiction shall determine upon the termination of the action." The amount of such security may be increased or decreased in the discretion of the court upon proper showing as to its adequacy or inadequacy.

The New Jersey statute is similar to New York's except that the statute clearly requires for exemption from liability for costs and expenses, that plaintiffs be holders of shares or voting trust certificates having a total par or stated capital value of not less than five per centum of the aggregate par value or stated capital value of all the outstanding shares of every class, exclusive of shares held in the treasury, unless the securities held have a market value in excess of $\$ 50,000$. It is expressly made retroactive, unlike the New York statute. ${ }^{11}$

In approving the New Jersey legislation (Chapter 131 of the New Jersey Laws of 1945), Governor Edge stated that its purpose was:

to deter the filing of irresponsible suits by persons who either have no legitimate cause of action or who institute such action more for the personal gain of a settlement out of court than in the interest of the corporation or its stockholders. These suits involving the highly complicated transactions of modern corporate businesses are very costly to defend, regardless of whether or not they may be justifiable. For this reason they have been the subject of great abuse and have been used to harass corporate officers and directors with baseless litigation .... It is a minimum protection for corporations and their officers and directors, against 'strike suits' . . . .

A similar statement was made by Governor Dewey in approving the New York legislation.

The basis of the New York, New Jersey and Pennsylvania acts is an arbitrary requirement of a large prescribed minimum interest on the part of the plaintiff as to a percentage of outstanding shares or (except in Pennsylvania) a designated market value. Liability for the defendants' costs and expenses and the putting up of security is imposed only on those plaintiffs who do not represent such an exceptionally large interest in the corporation. This requirement, it is said, has resulted in the practical abolition of derivative suits in New York. ${ }^{12}$ Leading New York corporation lawyers, however, generally hold a strong opinion that the only adequate protection against the

11 Stockholders' Derivative Suits in New Jersey (1947) RotGers L. REv. 117.

${ }^{12}$ Hornstein, The Death Knell of Stockholders Derivative Suits in New York (1944) 32 CaLIF. L. REv. 123, 125, 144; Hornstein, New Aspects of Stockholders' Derivalive Suits (1947) 47 CoI. L. REv. 1, 5, 32. 
abuses of derivative suits is under this statute, even though such suits are at present the only remedy a shareholder has to enforce accountability of management, which cannot be expected to sue itself.

The New York act does not draw any distinction, as the Wisconsin act does, between suits in which it is claimed that the management has taken unfair personal profits such as excessive incentive compensation or retirement provisions or misappropriation of corporate assets or opportunities, and suits in which the plaintiff questions only the acts and policies of the management in which they have no adverse interest.

The justification or rationale of the New York requirement of a large prescribed minimum stock interest or market value to eliminate suits brought in bad faith or without reasonable and probable cause may be regarded as founded on the following assumptions or postulates which are matters of opinion and personal experience rather than of impartial investigation of the facts generally: ${ }^{13}$

1. Presumably the minimum percentage or value of stock holding was not arbitrary but was chosen as the minimum holding which would give the plaintiff a sufficient interest in the corporation so that he would have a real stake in the recovery, and as a figure only high enough to deter speculators in attorney's fees and secret settlements. An interest less than the minimum is so small as to raise a conclusive presumption that the plaintiff is a strike suitor, motivated by personal, selfish gain rather than by concern for the welfare of the corporation.

2. If a small shareholder has a well founded complaint, and if there is a reasonable probability of success and benefit to the corporation, he will have little difficulty in getting the minimum amount of shares, required to bring a derivative suit without security, to join with him.

3. If shareholders have proof of serious wrongdoing, they can gain support from other shareholders, at least as to listed corporations, through the machinery established by the Securities and Exchange Commission in their proxy soliciting regulations.

4. As a general rule, shareholders who bring derivative suits have some personal axe to grind and do not seek in good faith the redress of corporate wrongs, there being no sufficient financial benefit to the holder of a small stock interest except possibly by sharing in attorneys' fees.

5. In general, it is asserted that the New York statute will not prevent the bringing of legitimate shareholders' suits, if there are any such.

1: See sipra note 12. 
As Justice Jackson put it in his opinion in Cohen v. Beneficial Industrial Loan Corporation:

The contention that the statute denies equal protection of the laws is based upon the fact that it enables a stockholder who owns $5 \%$ of a corporation's outstanding shares, or $\$ 50,000$ in market value, to proceed without either security or liability and imposes both upon those who elect to proceed with a smaller interest. We do not think the state is forbidden to use the amount of one's financial interest, which measures his individual injury from the misconduct to be redressed, as some measure of the good faith and responsibility of one who seeks at his own election to act as custodian of the interests of all stockholders, and as an indication that he volunteers for the large burdens of the litigation from a real sense of grievance and is not putting forward a claim to capitalize personally on its harassment value. These may not be the best ways of precluding "strike lawsuits," but we are unable to say that a classification for these purposes, based upon the percentage or market value of the stock alleged to be injured by the wrongs, is an unconstitutional one ....14

\section{Theory of the California Act: A Preliminary Inquiry}

The California statute adopts an entirely new basis for the imposition of litigation expenses by the requirement of security from the plaintiff. There is to be a preliminary inquiry upon motion of the corporation or the other defendants, by which they may apply to the court and establish by evidence at a hearing that there is no reasonable probability that the prosecution of the cause of action alleged in the complaint against the moving party will benefit the corporation or its security holders, or that the moving parties, if other than the corporation, did not participate in the transaction complained of. If the moving party establishes such a probability, the court is to fix the nature and amount of security to be furnished by the plaintiff for litigation expenses including those provided for under Corporations Code Section $830 .^{15}$

The California statute aims to throw the risk of loss on the plaintiff shareholder who volunteers to enforce alleged rights of action of the corporation only in those cases which may be called strike suits, where, in a preliminary inquiry, the corporation or other defendants can show that his action will probably not be of benefit to the corporation. Evidence would no doubt be admissible on the motion for

14 Supra note 7 at 552 .

15 The test of "reasonable probability" is the usual test as to the burden of proof in civil cases, whicb is less well expressed as "a preponderance of the evidence." It means a showing that there is no fair likelihood of benefit to the corporation, not that there is no foreseeable possibility or chance of slight benefit. 
security to the effect that the action is without any reasonable basis in fact or law, or is brought by the plaintiff and his attorneys for the purpose of annoying, harassing or holding up the corporation or its officials. The primary inquiry is whether the maintenance of the suit will probably produce more harm than good to the corporation and the persons having a real financial stake in it.

Section 834 (b) does not purport to impose any personal obligation or liability on the plaintiff for the costs and expenses of the defendants, except as that is implied in giving the bond or other security for them. The court is to fix the nature and amount of security to be furnished by the plaintiff to the moving party and the corporation. "The corporation and the moving party shall have recourse to such security in such amount as the Court shall determine upon the termination of such action." There is thus no personal obligation to pay costs and expenses except insofar as security is given and an action is brought on the bond given as security. The entire obligation of the plaintiff and his sureties is represented by the bond or other security, which limits but does not measure the liability.

The defendants will not be entitled to recover their costs and expenses from an unsuccessful plaintiff upon the termination of the action if they have not exercised their statutory right to obtain security during the proceedings and within the time limited. Since the liability and remedy are created by statute, there can be no recovery except "by recourse to the security" as provided by the statute. This seems also the situation under the New York act from which the provisions with reference to recourse to the security have been substantially taken.

No power is given in Section 834 to include the amount determined to be the reasonable expenses upon the termination of the action in any judgment for the defendants, as by motion of respondent for judgment against sureties on a supersedeas bond on appeal, without the necessity of an independent action. ${ }^{16}$ Under the Pennsylvania act, however, the amount of the expenses assessed will be awarded as costs of the suit and be recovered in the same manner as statutory taxable costs.

16 See Car. Cone Civ. Proc. \$ 942. See also Fed. R. Crv. P. 73f. Under section 830, Corporations Code, the indemnity for the reasonable expenses of directors, officers or employees may be "assessed" against the corporation by the court in the same or in a separate proceeding. It is not expressly stated that the court is authorized to make an award of such expenses by judgment against the corporation in the same proceeding although this power may reasonably be impled from the word "assessed," as there would he no other issues to be litigated. The word "assessed" may mean no more than "estahlish" but it may also mean levy or impose a liability. 4 WorDS AND Phrases (Perm. ed.) 409. 
Vague Federal Securities Exchange Act Provision for Expenses and Attorneys' Fees

A somewhat similar requirement to that of the California act is contained in the Securities Exchange Act of 1934, Section 9(b) as to certain classes of cases. ${ }^{17}$ The federal act, however, does not give the court any clear, guiding principle as to its application except in its own discretion. It provides that

... in any such suit the court may, in its discretion, require an undertaking for the payment of the costs of such suit, and assess reasonable costs, including reasonable attorneys' fees, against either party litigant.

In Stella v. Kaiser ${ }^{18}$ Kaufman, D. J., states a formula for the exercise of judicial discretion in cases to which the foregoing section is applicable: "The test-question is: Is the action brought in good faith and on a meritorious claim? The burden is on the moving defendants to satisfy the court that the test-question should be answered in the negative." As the Court points out in its opinion, "It is traditional that the right to resort to the courts should remain untrammeled; that justice should be made available to all at the least possible expense, and that in the absence of affirmative proof of special circumstances showing justification therefor, a plaintiff should not be required to secure the defendant against his expenses, legal or otherwise. The necessary affirmative proof by defendants has not been made here."

\section{Demand on the Directors and Copy of Complaint}

Under Section 834(a) (2) the plaintiff in an action instituted or maintained in the right of any domestic or foreign corporation must allege

in the complaint with particularity his efforts to secure from the board of directors such action as he desires and allege further that he has either informed the corporation or such board of directors in writing of the ultimate facts of each cause of action against each defendant director or delivered to the corporation or such board of directors a true copy of the complaint which he proposes to file, and the reasons for his failure to obtain such action or the reasons for not making such effort.

It is to be observed that this section requires efforts to secure action by the board of directors and a notice to such board of the

\footnotetext{
${ }^{17}$ Stat. 15 U.S.C.A. $78 \mathrm{i}(\mathrm{e})$. See also comparable provisions requiring security for costs "including reasonable attorney's fees" in Securities Act of 1933, \& 11e, 15 U.S.C.A. $\S 77 \mathrm{~K}(\mathrm{e})$ and Trust Indenture Act of $1939, \S 315(\mathrm{e}), 15$ U.S.C.A. $\S 770000(\mathrm{e})$.

18 (S. D.N.Y. 1949) 83 F. Supp. 431, 432, citing Acker v. Schulte (S.D.N.Y. 1947) 74 F. Supp. $683,689$.
} 
facts of each cause of action. It does not require any efforts to secure action from the shareholders or excuse therefrom, as required under Federal Rule 23(b). Any demand on the shareholders is an unreasonable and futile requirement. ${ }^{19}$

\section{Grounds of Motion}

Under Section 834(b) it is provided that

In any such action, at any time within thirty days after service of summons upon the corporation or any defendant, the corporation or such defendant may move the court for an order, upon notice and hearing, requiring the plaintiff to furnish security as hereinafter provided. Such motion may be based upon one or more of the following grounds:

(1) That there is no reasonable probability that the prosecution of the cause of action alleged in the complaint against the moving party will benefit the corporation or its security holders;

(2) That the moving party, if other than the corporation, did not participate in the transaction complained of in any capacity.

\section{Time for Application by Defendants}

It is to be noted that under the California act a motion must be made for the order requiring the plaintiff to furnish security by the corporation or by any defendant at any time within thirty days after service of summons. The court may on application for good cause shown extend such period for additional periods not exceeding 60 days. The New York and New Jersey statutes on the other hand authorize application for security for costs "at any stage of the proceedings before final judgment." It would seem to be a very great hardship upon the plaintiff to have such a demand made for security at a late state of the proceedings after he had expended much time and money in carrying on the trial. The California act contemplates a preliminary inquiry as to the possible beneficial nature of the action which in some cases or as to some defendants at least may obviate the necessity for any further steps in the litigation.

\section{Similar Suggestion by New Jersey Court}

Heretofore the defense has not been available to the corporation defendant in a shareholder's suit that the suit was being prosecuted from wrongful or malicious motives, ${ }^{20}$ or that there was not a reasonable prospect of benefit to the corporation from its prosecution. The New Jersey court as long ago as 1905 suggested that the court, even without the aid of statute, might entertain a petition on the part of the

\footnotetext{
193 Moore, Federal Practice, 3523, 3528 (2d ed. 1948).

20 Eshelman v. Keenan (Del. Ch. 1935) 181 Atl. 655; Battantane, CorporaTIONS 354 (1946).
} 
corporation to object to and question the power of the complainant to mamtain such a suit on the ground that it would endanger rather than advance the interest of the corporation. This suggestion was made by Vice Chancellor Garrison in Groel v. United Electric Co. of New Jersey, as follows: ${ }^{21}$

The formal defendant (the corporation) should have the right to object to and to question the power of the complainant to bring a suit in its behalf, but I do not think that the form in which it should raise this objection should be by plea or answer or demurrer. ... If we should adopt a practice by which the formal defendant should raise its objection by a petition setting forth such facts as it thought relevant and giving the reasons why it thought the complaining stockholder should not be permitted to prosecute a suit in its behalf, the court could, upon such an issue, properly determine the only question that ever should be permitted to be litigated between the formal defendant and the complainant without in any way interfering with the real meritorious issue against the actual defendant.22

Perhaps a petition stating the facts and reasons why it is claimed that the action would not be for the benefit of the corporation would have been a better procedure than a motion under Section 834 , unless the moving party is required by the court to give adequate notice to the plaintiff of his specific contentions, just as the plaintiff is required to inform the defendants.

\section{Conflicting Interests of Corporation and Other Defendants}

It is important to note that in general the corporate defendant is a passive beneficiary, required to take and maintain a wholly neutral position in derivative suits, taking sides neither with the complaining stockholder nor with the defending directors or officers. ${ }^{23}$ There are, however, some exceptions to this required passivity, although it is uncertain under certain decisions as to how far the corporation may go in setting up an objection to the suit or to the relief asked, such as a receivership, when this is deemed necessary for the protection of its interests. ${ }^{24}$

21 (1905) 70 N. J. Eq. 616, 625, 61 Atl. 1061, 1064. This suggestion was recently quoted in Slutzker v. Rieber (1942) 132 N. J. Eq. 412, 28 A. (2d) 528, 529, 530.

22 Professor George T. Washington discussed this suggestion of Vice Chancellor Garrison in the course of an able article, Stockholders Derivative Sutits: the Conpany's Role, and a Suggestion (1940) 25 CoRN. L. Q. 361, 371, but he did not advocate its adoption as a solution for the regulation of derivative suits. This article furnishes useful suggestions which will help in interpreting the California act.

23 Meyers v. Smith (1933) 190 Minn. 157, 251 N. W. 20; Solimine v. Hollander (1941) 129 N. J. Eq. 264, 267, 19 A. (2d) 344, 346; Slutzker v. Rieberg (1942) 132 N. J. Eq. 412, 28 A. (2d) 528, 530 (collecting cases); Chaplin v. Selznick (1945) 186 Misc. 66, 58 N.Y.S. (2d) 453; Batlantine, Corporations 366 (1946). See supra note 18.

24 Otis \& Co. v. Pennsylvania R. Co. (E. D. Pa. 1944) 57 F. Supp. 680 af'd. (1946) 61 F. Supp. 905, 155 F. (2d) 522, noted in (1945) 31 VA. L. REv. 695. See Note (1934) 43 YALE L. J. 661, 663. 
The interests of the corporation and of the directors and officers who are sued for misconduct are generally conflicting. It would ordinarily be improper for the attorneys of the individual defendants to act also for the corporation defendant, which is in substance the plaintiff, particularly by interposing defenses or answers on the merits to the alleged corporate right of action. The management cannot properly use corporate funds to assist the individual defendants to resist the prosecution of the corporate right of action against them. ${ }^{25}$ With reference to the motion for security for costs under the California act, there may be some question as to when the same attorneys may properly act for the corporation and for the other defendants. It would seem that there is here grave danger of a conflict of interest and breach of fiduciary duty.

\section{Determination by Court as to Plaintiff's Furnishing Security for Expenses of One or More Defendants}

Section 834(b), next to the last paragraph, provides that if the court determines, after hearing the evidence, that the moving party has established a probability in support of any of the grounds upon which the motion is based, the court shall fix the nature and amount of security to be furnished by the plaintiff for reasonable expenses, including attorney's fees. These expenses are those "which may be incurred by the moving party and the corporation in connection with such action, including expenses for which the corporation may become liable pursuant to Section 830," Corporations Code. This is broad enough to cover the expenses of litigating the motion for security if a defendant, other than the corporation, is finally successful in whole or in part, and is found to merit indemnity.

This provision of Section 834 , literally read, does not make the right to recover expenses by each defendant against the plaintiff dependent upon his being a director, officer or employee or upon the defendant being successful in whole or in part, or upon a finding by the court that his conduct fairly and equitably inerits such indemmity, as is provided under Section 830, Corporations Code, in order that a defendant may have recourse for indemnity against the corporation. The reference, however, to Section 830 may be taken to imply that the right to indemnity of any defendant director, officer or employee is dependent upon an application under Section 830, complying with the tests prescribed in that section. ${ }^{26}$ It would be an unfortunate construction, not intended by those who drafted this legis-

26 Elberta Oil Co. v. Superior Court (1930) 108 Cal. App. 344, 291 Pac. 668. Cf. Otis \& Co. v. Pennsylvania R. Co., supra note 24.

26 See Ballantine, California's 1943 Statute as to Directors Litigation Expenses (1943) 31 Calif. L. Rev. 515; as to Calif. Corps. Code see $\$ 830$. 
lation, for a defendant to recover indemnity against the plaintiff for expenses due to his wrongful acts against the corporation in breach of his duty to it. The main purpose of Section 834 is to shift the risk of any defendant's expenses from the corporation to the plaintiff "in such amount as the court shall determine upon the termination of the action." Indemmity is an equitable right to be awarded only when the defendant is successful in whole or in part, not to a wrongdoer.

This is certainly the statutory scheme of the New York act under Section 61b, General Corporation Law. In New York it is only the corporation which is authorized to apply for security for reasonable expenses which may be incurred by it and by the other parties defendant for which it may become liable pursuant to Section 64 on application under Sections 65 to 67 of the General Corporation Law. Officers and directors are entitled to indemnity, under Section 64 , except in relation to matters as to which it is adjudged that they are liable for negligence or misconduct in the performance of their duties.

The expenses and attorneys' fees incurred by the corporation, as distinguished from the other defendants, in making and litigating a motion for security for costs do not seem to be included in Section 834 , as the statute speaks of "the probable reasonable expenses of the corporation and the moving party which will be incurred in the defense of the action." Section 830, however, is very broad and covers expenses of a person sued because he is or was a director, officer or employee of a corporation, domestic or foreign, in any proceeding arising out of his alleged misfeasance or nonfeasance in the performance of his duties or out of any alleged wrongful act against or by the corporation incurred in defense of the proceeding. Indemnity for his reasonable expenses including attorneys' fees may be assessed against the corporation under Section 830 if the director, officer or employee sued is successful in whole or in part and the court finds that his conduct fairly and equitably merits such indemnity.

Section 834(b) provides that "If the court upon any such motion makes a determination that security shall be furnished by the plaintiff as to any one or more defendants, the action shall be dismissed as to such defendants, unless the security required by the court shall have been furnished within such reasonable time as may be fixed by the court."

This shows the reason why the California act provides for applications not only by the corporation (as under the New York and New Jersey acts) but also by each defendant. The plaintiff may be led to dismiss the action as to certain defendants as to whom he is required to furnish security for costs and to proceed only as to other defendants as to whom no improbability of benefit from the suit has been shown. 


\section{When the Statute Is, and When It Is Not, Applicable}

The statute as to security for expenses does not apply when the suit is brought by a shareholder against a corporation in his own right, or as a class suit in which he sues as a representative of his own direct rights and those of other shareholders. Thus in Lennan v. Blakeley ${ }^{27}$ the court denied a motion to compel the plaintiff to furnish security for expenses under Section 61(b), New York General Corporation $\mathrm{Law}$, where the plaintiff sued as a representative of a class of which he was a member and no relief was sought for the benefit of the corporation. The plaintiff did not sue in the right of the corporation but in his own behalf and for all others similarly situated..$^{28}$ The California act, like the New York act, does not provide that it shall be retroactive or apply to actions pending before the date when it goes into effect. ${ }^{29}$ The express New Jersey provision for retroactivity is very unfair.

It has been held in Cohen v. Beneficial Industrial Loan Corp. ${ }^{30}$ that in a shareholders' derivative suit the federal court must apply a state statute requiring the plaintiff to give security for defendant's counsel fees. The federal courts are required to follow the state policy of heading off strike suits and may not provide an avenue for evasion of the state's declared policy by resort to the federal courts. ${ }^{31}$

Under the New York act ( $\$ 61 \mathrm{~b}$ Gen. Corp. Law) the plaintiff may be required to furnish security for the reasonable expenses, including attorney's fees, which may be incurred by the corporation "and by other parties defendant in connection therewith for which it may become subject pursuant to section sixty-four of this chapter." Section 64, New York Gen. Corp. Law, corresponds to Section 830, Cal. Corp. Code, which relates to indemnity to directors, officers and employees by the corporation. Those who drafted the California act in Assembly Bill No. 428 omitted the New York qualifying clause limiting security to those defendants who are directors, officers and employees. Any stranger defendant is also given the right to indemnity against a plaintiff in a derivative suit. It goes beyond the New York requirement to give this right to indemnity to stranger defend-

$2 \pi$ (Sup. Ct. 194S) 80 N. Y.S. (2d) 288.

28 See as to shareholder's direct right of action against a corporation as contrasted with a derivative suit, Sutter v. General Petroleum Corp. (1946) $2 \mathrm{~S}$ Cal. (2d) 525, 170 P. (2d) 898, 901; Note, Shareholder's Right to Individual Relief (1947) 35 CaLIF. L. Rev. 453; Ballantine, Corporations 333-340 (1946).

20 Schielcrawt v. Moffett, supra note 8; Coane v. American Distilling Co. (1948) 298 N.Y. 197, 81 N.E. (2d) 87 , noted in (1949) 34 CoRN. I. Q. 437, Retroactivity of § 61 Gen. Corp. Law.

30 (1949) 337 U.S. 541, affirming (C. C. A. 3d 1948) 170 F. (2d) 44.

31 Notes, (1948) 62 Harv. L. Rev. 309, (1948) 48 Cor. L. Rev. 435, (1949) 23 St. JoHr's L. REv. 296, 304. 
ants to whom the corporation would not be liable for expenses and counsel fees if they were sued by the corporation or in a derivative suit.

\section{Fiduciary Duty of Plaintiff for Private Settlements}

The fiduciary concept furnishes an important power of judicial regulation of derivative suits. It has been the possibility of securing a lucrative private settlement or compromise without regard to the interests of the corporation that has made the remedy by derivative suit especially subject to abuse in New York and some other jurisdictions. ${ }^{32}$ The fiduciary position of the plaintiff in such suits has long been established in the federal courts under the Federal Rules of Civil Procedure 23(c). ${ }^{33}$ It has also been the rule in California under the leading decision of Whitten v. Dabney. ${ }^{34}$ It was there held that the plaintiff is a fiduciary in suing on behalf of a corporation and will not be permitted to compromise, settle or take any action which has not first received the sanction of the court after scrutiny and examination to protect the corporation's rights. It was declared to be the right and duty of the court to exercise supervision over the conduct of the fiduciary. This fiduciary duty has been applied to hold that the plaintiff could not dismiss an action in his fiduciary capacity as to the corporation without the sanction of the trial court. ${ }^{35}$ Under the Federal Rule a derivative suit will not be dismissed or compromised without approval of the court upon such notice as the court may direct.

The fiduciary rule of accountability to the corporation for the proceeds of such a suit was not clearly declared by the courts of New York until 1947. ${ }^{36}$ In New York it had been held that the plaintiff had complete dominion over his derivative action and was free to stipulate with the defendant for a discontinuance. ${ }^{3 r}$ The fiduciary principle has now been applied in New York to accountability to the corporation for the proceeds realized from the litigation by judgment or by settlement with the court's approval or by private settlement

32 Notes, (1946) 13 U. of Chr. L. Rev. 321, 329, (1947) 42 Ir工. L. REv. 667, 669; (1948) Wxsc. L. Rev. 580, 581; McLaughlin, Capacity of Plaintiff-Stockholder to Terminate a Stockholder's Suit (1936) 46 YALE L. J. 421.

333 MOORE, Frderal Practice, 3549, 3555 (2d. ed. 1948).

34 (1915) 171 Cal. 621, 154 Pac. 312.

35 Spellacy v. Superior Court (1937) 23 Cal. App. (2d) 142, 72 P. (2d) 262, (1938) 26 CALIF. L. Rev. 261 cited in Riley v. Dunbar (1942) 55 Cal. App. (2d) 452, 130 P. (2d) 771,772 .

36 Clarke v. Greenberg (1947) 296 N. Y. 146, 71 N. E. (2d) 443. See Note, Application of Rule of Young v. Higbee (1946) 13 U. CHI. L. REv. 321, 328; McLaughlin(1936) 46 YALE. L. J. 421, 430.

${ }^{37}$ Manufacturers' Mut. Fire Ins. Co. v. Hopson (1940) 176 Misc. 220, 25 N. Y. S. (2d) 502,508 , aff'd. (1942) 288 N.Y. 668,43 N.E. (2d) 71 on point that stipulation of discontinuance is effectual to terminate action. Note, 24 N.Y. U. L.Q. REv. 395 (1949). See Winkelman v. General Motors Corp. (S.D. N. X. 1942) 48 F. Supp. 490,494 . 
and discontinuance of the action, but not as yet to court control of the mere dismissal or discontinuance of the action, as in the federal courts and in California. ${ }^{38}$

\section{May Attorneys Properly Instigate Derivative Suits?}

A shareholder, before he volunteers as plaintiff to champion the cause of his corporation's right of action, must give consideration to the time, trouble and expense of bringing such a suit and the loss in which he will be involved if he fails to succeed. Since the incentive which the law holds out to make possible the bringing of derivative suits is not any compensation to the plaintiff himself, but a counsel fee to the plaintiff's attorney, it may be desirable not to discourage competent lawyers from instigating shareholders' suits if the suit can be prosecuted and settled only under proper regulation. A liberal allowance of counsel fees is made to plaintiff's counsel according to the benefits secured, as this is the dynamic factor giving the necessary impetus to the volunteer method of representation in class and derivative suits. ${ }^{30}$ Otherwise no shareholder could possibly afford to begin a suit of such size and extreme difficulty with only a comparatively small individual interest in it.

\section{Disqualification of Prior Transferees to Sue For Corporation}

A provision of Section 834(a) (1) of the Corporations Code adopts the so-called contemporaneous ownership restriction upon the qualification of a shareholder to sue. It provides:

No action may be instituted or maintained in the right of any domestic or foreign corporation or by the holder or holders of shares, or voting trust certificates representing shares of such corporation, unless $* * *$ (1) The plaintiff alleges in the complaint that he was a registered shareholder or holder of voting trust certificates at the time of the transaction or any part thereof of which he complains or that his shares of voting trust certificates thereafter devolved upon him by operation of law from a holder who was a holder at the time of the transaction.

A similar provision has long been established by the Federal Rules of Civil Procedure ${ }^{40}$ and is incorporated in the statutes of New York,

38 Certain-Teed Products Corporation v. Topping (C. C. A. 2d 1948) 171 F. (2d) 241; Winkelman v. General Motors Corp. (S. D. N. Y. 1940) 39 F. Supp. 826, 831.

39 Kalven and Rosenfield, The Contemporary Function of the Chass Suit (1941) $8 \mathrm{U}$. OF CHr. L. REv. 684, 716, "the striking thing is that though the fees may be large and attractive, they are awarded only on a quantum-meruit basis." See also Hornstein, The Counsel Fee in Stockholders' Derivative Suits (1939) 39 CoL. L. REv. 784, 791, 814; (1947) 47 CoL. L. REv. 1, 25-30; Comment, Right to Attorneys' Fees in Shareholders' Derivalive Suit (1942) 30 CalrF. L. Rev. 667; Ann. 152 A. L. R. 909, 914; Ballantine, CORPORATIONS 368-371 (1946).

40 Fed. R. Crv. P., 23(b); Ann. 148 A. L. R. 1097, 1099. 
Delaware and New Jersey. This was formerly not required in New York ${ }^{41}$ nor in Delaware; ${ }^{42}$ nor has it been required by decision or statute in California.

In Harvey v. Meigs ${ }^{43}$ the court said, ". . . if the defendants ... fraudulently misappropriated $\$ 94,000$ of the corporate funds which should be restored to the treasury, I fail to see why they [the plaintiffs] have not a cause of action to compel such return even though they acquired their shares after such misappropriation." This is a sound rule on principle as each share represents an interest in the entire concern and the several shareholders are entitled to equal rights irrespective of when they acquired their shares. The corporate cause of action is enforced for the benefit of all the shareholders. ${ }^{44}$

This disqualification of prior transferees has no connection with other parts of Corporations Code Section 834. The explanation of how it came to be included is that the original sponsors of this legislation in Assembly Bill 428 were attorneys representing corporations and their officers who were much concerned about the danger of abuse of shareholders' derivative suits. They desired if possible to secure in California the adoption of the entire New York restrictive legislation. A conference was called when they encountered serious opposition to their proposals by those who considered the New York act too drastic. The bill was redrafted to include the novel provision with reference to preliminary inquiry by the court as to whether the suit could be shown by the defendants to be a nonbeneficial one. The sponsors, however, insisted on the disqualification provision as under the Federal Rule and the New York, New Jersey, and Pennsylvania statutes.

A provision was urged limiting the disqualification to those who acquired shares only for the purpose of bringing suit. It was objected, however, that this is a matter too difficult to prove, although it is the law in a number of jurisdictions. This idea was expressed in 1884 by a dictum in Dimpfell v. Ohio \& Mississippi R. Co. ${ }^{45}$ The court there intimated that the policy of the Federal Rule disqualifying subsequent transferees was to prevent the plaintiff from purchasing shares for the purposes of suit, "... to annoy and vex the company, in the hope that they might thereby extort, from its fears, a larger benefit than

41 Pollitz v. Gould (1911) 202 N.Y. 11, 94 N.E. 1088, 38 L.R.A. N.S. 988; Ann. 148 A. L. R. 1094. See Seasongood, Stockholder Suing for Corporation (1907) 21 FaRv. L. Rev. 195.

42 Rosenthal v. Burry Biscuit Corp. (Del. Ch. 1948) 60 A. (2d) 106, 110.

43 (1911) 17 Cal. App. 353 at 364, 119 Pac. 941 at 945.

44 Overfield v. Pennroad (D. C. Pa. 1943) 48 F. Supp. 1008, 1018. Ann. 148 A. L. R. $1090,1094$.

45 (1884) 110 U.S. 209, 210. See Ann. 148 A.L.R. 1090, 1101, purchase of stock for purpose of suit. 
the other shareholders ... or compel the company to buy their shares at prices above the market value."

Under the California law as changed by the statute it will now be necessary for plaintiffs in a derivative suit to set forth in their complaints the dates when they became holders of their shares so that it may be disclosed whether and to what extent the plaintiffs have capacity to sue. ${ }^{46}$ This is considered by the writer to be an unfortunate change in the existing law.

In the case of continuing transactions or wrongs the California disqualification relaxes the federal rule to some extent, so that it is not necessary for the plaintiff to go back to prove the exact starting point of a continuing wrongful transaction during which he acquired his shares, but he will have a right to sue for the entire transaction if he was a holder during "any part thereof." "47 Even so the disqualification of subsequent transferees has the unfortunate effect of limiting recovery by the corporation in a derivative suit to an arbitrary period dating from the time the plaintiff shareholder acquired his shares or was a holder during some part of this transaction complained of, although the corporation may have valid claims against the defendants arising prior to that date. This restriction seems clearly unsound $\mathrm{m}$ principle because the basis of recovery in a derivative suit is not some special or indirect injury to the plaintiff shareholder by impairing the value of his shares, but injury to the corporation. ${ }^{48}$ Every shareholder, prior or subsequent, has an interest in having the corporation assert its rights of action and protect and recover its assets and is damaged by its failure to do so. Under the California act sufficient protection agaimst the expenses of groundless suits should be found in the preliminary inquiry as to the prospect of benefit being derived from the suit, without any disqualification of subsequent shareholders to sue.

The California act has indeed introduced a disqualification which, in one respect, goes even beyond that of New York, New Jersey, Dela-

46 Austin v. Gardiner (1947) 186 Misc. 538, 68 N. Y.S. 2d 664; Milton v. Krivet (Sup. Ct. 1948), 82 N. Y. S. (2d) 38; 3 Moore, Feperal, Practice 3499, 3521 (2d. ed. 1948). "It may be that there is no such stockholder because of share transfers."

47 In Cohn v. Beneficial Industrial Loan Corporation, supra note 7, the complaint alleged tbat since 1929 the individual defendants engaged in a continuing and successful conspiracy to enrich tbemselves at the expense of the corporation. The mismanagement and fraud extended over a period of eighteen years and the assets wasted or diverted thereby were alleged to exceed $\$ 100,000,000$. The plaintiffs holding one hundred out of two million shares, approximately 0.0125 per cent, of the outstanding stock which had a market value of around $\$ 9,000$, brought the suit. The corporation defendant demanded a bond of $\$ 125,000$ for expenses and counsel fees.

48 Turner v. Markbam (1909) 155 Cal. 562, 102 Pac. 272, 275; Shenberg v. De Garmo (1943) 61 Cal. App. (2d) 326, 143 P. (2d) 74; Winkleman v. General Motors Corp. (1942) 48 F. Supp. 490; BaILANTINE, CoRporations 352, 353 (1946). 
ware and the Federal Rule, in that it requires that the plaintiff be a "registered shareholder" in order to sue. In the federal courts and in New York, New Jersey and other jurisdictions generally, it is sufficient that the plaintiff be an equitable shareholder or unregistered owner of shares. This has been the doctrine in California going back to $1871 .{ }^{49}$

\section{Appealability of Order Granting or Refusing to Grant Security}

An order granting or refusing to grant security is in the nature of a final judgment in a collateral or ancillary proceeding, but it does not seem to be included under appealable orders in section 963 of the Code of Civil Procedure. In Cohen v. Beneficial Industrial Loan Corporation ${ }^{50}$ it was held that in a stockholder's derivative action in the federal court under the New Jersey statute an order denying a corporate defendant's motion to require plaintiff to give security for reasonable expenses, including attorneys' fees, was an appealable "final decision" under a liberal interpretation of the federal statute as to appeals from orders other than final judgments when they have final and irreparable effect on the rights of the parties. As Mr. Justice Jackson points out, a claim under the statute for security is a claim of collateral right asserted in the action too important to be denied review independent of the cause of action itself and too important to be deferred until the whole case has been adjudged.1 The right to appeal, however, refers to the right to security and not to an exercise of judicial discretion of the trial court as to its amount.

\section{Tentative Conclusions}

Shareholders' suits have been much less numerous in California than in New York and some other eastern states. Abuses of such suits, if any, have not yet come to public notice. Experience elsewhere indicates that it is a prudent precaution to attempt some reasonable regulation to prevent strike suits. Great evils, however, will result if undue obstacles are placed in the path of a shareholder who has legitimate grounds for suing. The derivative action is practically the only remedy for calling the management to account for its wrongs against the corporation and to obtain restitution. ${ }^{52}$ Where a derivative suit is

49 Parrott v. Byers (1871) 40 Cal. 614, 625. See Gallup v. Caldwell (C. C. A. 3d 1941) 120 F. (2d) 90, 94; H.F. G. Co. v. Pioneer Pub. Co. (C.C.A. 7th 1947) 162 F. (2d) 536; Rosenthal v. Burry Biscuit Co. supra note 37, noted (1948) 34 VA. L. REv. 837. See 1947 AnNual Survey of Amierican Law 654, note, Who is a Shareholder Under Federal Rule 23(b), (1948) 46 Mich, L. Rev. 431. 3 Moore, Federal Practice, 3517 (2d ed. 1948).

50 See supra note 7.

51 See 4 C. J.S., Appeal and Error, 194, 198; 2 CaL. Jur, Appeal and Error, $\$ 23$.

52 Purcell, Foster and Hill, Enforcing the Accountability of Corporale Managemenl, (1946) 32 VA. L. Rev. 497 ; Frey, Noteworthy Decisions in the Law of Privale Corpora. tions: 1940-1945 (1946) 94 U. OF PA. L. REV. 265. 
against outsiders for wrongs against the corporation the directors can usually be expected to decide impartially on the advisability of suing. But the management cannot be expected to sue themselves for their own misdeeds. By such wrongs the value of each shareholder's shareholdings will be depreciated and impaired to a greater or less extent, but ordinarily he cannot bring a direct action against the wrongdoers for his individual damages for what are regarded, to avoid multiplicity of suits and for the protection of creditors, as wrongs against the corporation.

The California statute does not put a complete stop to a derivative suit even if the defendants succeed in showing a probability that it is not for the benefit of the corporation. It only imposes the risk of loss of the defendants' litigation expenses upon the plaintiff in event of his failure in whole or in part. It does not provide for a motion for dismissal or summary judgment. ${ }^{53}$

As the United States Supreme Court has held, the state legislatures have a wide and flexible power of regulation of derivative suits. But it is a fundamental policy of the law and duty of government that some remedy must be provided for every recognized wrong. ${ }^{54}$

There is a strong implied admonition in Mr. Justice Jackson's excellent description of the history and function of the shareholder's derivative action in Cohen v. Beneficial Industrial Loan Corporation as follows:

... As business enterprise increasingly sought the advantages of incorporation, management became vested with almost uncontrolled discretion in handling other people's money. The vast aggregate of funds committed to corporate control came to be drawn to a considerable extent from numerous and scattered holders of small interests. The director was not subject to an effective accountability. That created strong temptations for managers to profit personally at expense of their trust. The business code became all too tolerant of such practices. Corporate laws were lax and were not self-enforcing, and stockholders, in face of gravest abuses, were singularly impotent in obtaining redress of abuses of trust.

Equity came to the relief of the stockholder, who had no standing to bring civil action at law against faithless directors and managers. Equity, however, allowed him to step into the corporation's shoes and to seek in its right the restitution he could not demand in his own. It required him first to demand that the corporation vindicate its own rights but when, as was usual, those who perpetrated the wrongs also

53 See Levine v. Behn (1938) 8 N. Y.S. (2d) 58, rev'd. (1940) 282 N. Y. 120,25 N. E. (2d) 871.

ut CaL. Civ. Code $\$ 3523$. See 1 CaL. JUR., Actions $\$ 19$; Note (1947) 42 ILL. L. Rev. 233, 237; Note (1948) Wisc. I. Rev. 580. 
were able to obstruct any remedy, equity would hear and adjudge the corporation's cause through its stockholder with the corporation as a defendant, albeit a rather nominal one. This remedy born of stockholder helplessness was long the chief regulator of corporate management and has afforded no small incentive to avoid at least grosser forms of betrayal of stockholders' interests. It is argued, and not without reason, that without it there would be little practical check on such abuses. 55

The sharply conflicting views as to "security-for-expenses" requirements in derivative suits of able corporation lawyers, teachers of corporation law and corporate managers show that the problem of derivative suit regulation is a national one of management-investor relations, on which there is little prospect of early agreement. If the effective judicial enforcement of fiduciary duties of management has broken down, the protection of the shareholder will have to be found in proxy fights and shareholders' meetings, and perhaps before state and federal commissions which could at least investigate and report on grievances. 